Check for updates

The BMJ

Cite this as: BMJ 2021;372:n218 http://dx.doi.org/10.1136/bmi.n218 Published: 25 January 2021

\section{Sixty seconds on ... naming strains}

Tom Moberly

\section{What's in a name?}

General bewilderment, it turns out, when we're talking about SARS-CoV-2 variants. More and more potentially worrying variants are being identified, but there's no agreed way of naming them. A report in Nature this month said that researchers are being left in a world of confusion. ${ }^{1}$ Even terms like "variant," "lineage," and "strain" don't have unambiguous definitions.

\section{Naming strains is a strain?}

Exactly. "All of us are becoming very confused by the different variant names," said Maria Van Kerkhove, covid-19 technical lead for the World Health Organization. Or, as Tulio de Oliveira, a bioinformatician at the University of KwaZulu-Natal in Durban, put it, "The nomenclature is a bloody mess at the moment."

\section{Haven't we been here before?}

With covid-19? Well, yes, we did all have to get used to a couple of names for the virus and the disease. Before February 2020, the SARS-CoV-2 virus was known as nCoV2019 or 2019-nCoV, and the covid-19 disease was referred to as 2019-nCoV acute respiratory disease.

\section{What about the catchy "B.1.1.7"?}

That's just one name for that particular variant-the strain formerly known as "variant under investigation 202012/01." It has also been known as "variant of concern 202012/01" and 20I/501Y.V1, and the media have called it "the UK variant" and even "the Kent variant."

\section{What's wrong "the UK variant"?}

Geographical names are one of the things people are trying to avoid-variants spread from country to country quickly and may emerge in one country but be identified in another. Also, geographical associations could discourage people from reporting worrying new variants and stigmatise particular countries.

\section{Naming and shaming?}

That's what we want to avoid. Donald Trump repeatedly labelled SARS-CoV-2 the "Chinese virus" as part in a public relations campaign that coincided with a rise in attacks and harassment of Asian American medical staff in the US

\section{Is someone sorting this out?}

They're trying to. At a WHO meeting on 12 January it was agreed that a consensus naming system for variants should be developed, and a working group is now taking ideas forward.

\section{How about having a public vote?}

Maybe not-we could end up with "Strainy McStrain Face.”

1 Callaway E. "A bloody mess": confusion reigns over naming of new covid variants. 15 January. www.nature.com/articles/d41586-021-00097-w. 